have not the same properties. Gelatine, unlike osseine, does not exist in organism, but is produced by chemical transformation resulting from the action of water and heat upon the bony tissue; gelatine, moreover, is completely soluble in water, while osseine is not so. For these reasons the two substances would doubtless be different in their alimentary capacities, and deductions drawn from the influence of one upon the human system ought not in any way to prejudice the other. Of course, says M. Fremy, osseine cannot be expected to fulfil the same duty as a complete aliment; such, for instance, as bread, or meat, but nust be employed in conjunction with some other suitable material. In the same way gluten, which is simply flour freed from starch, oil, and soluble substances, would alone be powerless to support life and bealth. If regarded in the same light as fibrine, casein, and albumen, and associated with other bodies, osseine would be found a valuable aliment. White meat, calf's head, neatsfoot, $\& c$, contain much bony tissue, and their nutritious qualities are incontestable.

Of this osseine, then, bones are said to contain 35 per cent, the mode of separation being simply to slice the bone very thinly, and to treat the same with dilute hydrochloric acid; hard white bones, free from fat, are most suitable, and some care and attention in manipulation is of course necessary, so that the product may be perfectly sweet and free from any taint or unpleasant odour. For if disgust is once aroused against this kind of food, as indeed against any other for that matter, no amount of pushing or puffing can force it into the public market. Should, therefore, any trace of acid be perceptible after preparation of the osseine, it is recommended that the product be treated with an alkali of some lind, for example, lime or carbonate of soda, but this must obviously be done with due care and discretion. The cost of this aliment is about one franc per pound, whereas gelatine of good quality costs from four to five francs.

As regards the best method of cooking or curing, $M$. Fremy recommends the swelling of the mass with hot water, and then boiling for about an hour, when the tissue becomes soft and pliable; it may be seasoned in the cooking, or may be allowed to cool and then kept for thirty-six hours in brine. If eaten warm with admixture of some fat and vegetables the osseine is decidedly palatable. Owing to its large constituent of nitrogen it is extremely nutritious, and, furthermore, fornis a comestible not liable to become putrid.

It is right to mention that on some of the points enumerated by M. Fremy, exception is taken by M. Dumas and others, who are not so confident of the real value of osseine as an alimentary substance, those gentlemen maintaining the injurious nature of gelatine; $M$. Chevreul, however, confirms to some extent M. Fremy, and states that osseine is decidedly more nutritious than gelatine.

Other measures for improving the alimentation of Paris were taken during the siege, but these for the most part present little novelty. Mr. Wilson's plan for salting the carcases intact, and thus preserving the meat in an almost fresh condition, was resorted to, that gentleman bringing his personal staff from Ireland to afford assistance just at the instant of closing the gates of the metropolis. The assistance of M. Georges, whose plan of preserving meat is both original and peculiar, was likewise cbtained ; this invention, which has been practised it is saidwith much success in America, is adapted more particularly for the curing of mutton rather than beef, and consists in treating the meat in a bath acidified with hydrochloric acid, and afterwards in a solution of sulphite of soda. In this condition, after further sprinkling with sulphite of soda, the flesh is packed in tins and soldered down: the sulphite of soda acting upon the hydrochloric acid gives rise to sea salt and sulphurous acid, thus ensuring the perfect preservation of the meat.

H. B. P.

\section{THE TEMPERATURE PRODUCED BY SOLAR RADIATION}

SIR ISAAC NEWTON determined the intensity of solar radiation by observing the increment of temperature of dry earth on being exposed to the sun. In the latitude of London at midsummer, dry earth acquires a temperature of $150^{\circ}$ in the sun at noon and $85^{\circ}$ in the shade, difference about $65^{\circ} \mathrm{Fah}$. This difference Sir Isaac Newton regarded as a true index of the intensity of solar radiation; hence his celebrated demonstration proving that the comet of 1680 was subjected to a temperature 7,000 times higher than that of boiling water $\left(212^{\circ} \times 7,000=1,484,000^{\circ} \mathrm{Fah}.\right) .^{*}$ The comet when in its perikelion being within one-third part of the radius of the sun from his surface, we have to add the diminution of temperature, 044 , attending the dispersion of the rays in passing through the solar atmosphere and the remainder of the stated distance from the sun. Accordingly, the demonstration showing that the comet of 1680 was subjected to a temperature 7,000 times higher than that of boiling water, establishes a solar temperature exceeding $2,640,000^{\circ}$; and if we add 0.21 for the retardation of the rays in traversing the terrestrial atmosphere, it will be found that the temperature deduced from the experiments with incandescent radiators, and our actinometer observations, differs scarcely $\frac{1}{5}$ from that roughly estimated by the author of the "Principia." In order to comprehend fully the merits of the method of determining solar intensity conceived by his master mind, let us imagine an extended surface of dry earth, one half of which is shaded, the other half being exposed to the sun. Dry earth being a powerfil absorbent and radiator, and at the same time a bad conductor, the central portion of the supposed surface evidently cannot suffer any loss of heat by lateral radiation; while the non-conducting property of the material prevents loss by conduction laterally or downwards. Consequently, no reduction of temperature can take piace excepting by radiation in the direction of the source of the heat. Removing the shade, during an investigation, it will be found that, notwithstanding the uninterrupted radiation of the exposed substance upwards, the intensity will gradually increase until an additional temperature of about $65^{\circ}$ Fah. has been acquired. Indisputably, this increase of temperature is due to unaided solar radiation. Evidently the accidental interference of currents of air need not be considered. Besides, if the dry earth is confined within a vacuum, such interference rnay be entirely obviated. It is scarcely necessary to point out that the generally-adopted mode of measuring the sun's radiant heat by thermometers, is in direct opposition to the principle involved in the method under consideration. 'The meteorologist, in place of preventing the bulb from radiating in all directions and guarding against loss of heat by convection, puts his thermometer on the grass, or suspends it on a post, one half of the convex area of the bulb receiving the sun's radiant heat, while the other half is permitted to radiate freely, the whole being exposed to the radiation from surrounding objects and to the refrigerating influence of accidental currents of air, in addition to the permanent current produced by the ascending heated column above the bulb. This explains the cause of the perplexing discrepancies in meteorological records. The extent of the diminution of intensity of solar radiation occasioned by cold air acting on the bulb, and by the latter radiating freely in all directions, is demonstrated in the most conclusive manner by the result of observations made with the instrument described by Père Secchi in

* Sir Isaac Newton has been criticised for comparing the temperature to scription," it is said in " " term of comparison indeed of a very vague de being correct, since the lemonstration fronomy. This criticism is far from term red-hot, viz, a temperature reference to red-heat, exceeded "two thousand times" 3 " 5 times water. The tended to furnish some a ceeded "two thousand times," was evidently intemperature involved in the computation.
the inconceivably high degree of 
TABLE A.-Showing the Temperature produced by Solar Radiation at Noon, for cach degree of Latitude, when the Earth is in Aphelion. Northern Hemisphere:-

\begin{tabular}{|c|c|c|c|c|c|c|c|c|c|c|}
\hline & - & Latitude. & $\begin{array}{l}\text { Solar } \\
\text { intensity } \\
\text { at Noon. }\end{array}$ & Latitude. & $\begin{array}{l}\text { Solar } \\
\text { intensity } \\
\text { at Noon. }\end{array}$ & Latitude. & $\begin{array}{l}\text { Solar } \\
\text { intensity } \\
\text { at Noon. }\end{array}$ & Latitude. & $\begin{array}{l}\text { Solar } \\
\text { intensity } \\
\text { at Noon. }\end{array}$ & \\
\hline & & Deg. & Fah. & Deg. & Fah. & Deg. & Fah. & Deg. & Fah. & \\
\hline Equator & $\ldots \quad \ldots$ & o & $65 \cdot 30$ & 24 & $67 \cdot 20$ & 49 & $64 \cdot 95$ & & & \\
\hline & & I & 65.45 & 25 & $67 \times 9$ & 50 & 64.77 & & & \\
\hline & & 2 & 65.60 & 26 & $67 \cdot 18$ & $5 \mathrm{I}$ & $64: 58$ & & & \\
\hline & & 3 & 65.75 & $\begin{array}{l}27 \\
28\end{array}$ & $67 \cdot 17$ & $5 \mathrm{I} \cdot 28$ & 64.8 & $\cdots \quad \cdots$ & 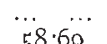 & Greenwich. \\
\hline & & $\begin{array}{l}4 \\
5\end{array}$ & $\begin{array}{l}65.89 \\
66.02\end{array}$ & $\begin{array}{l}28 \\
29\end{array}$ & $\begin{array}{l}0714 \\
67 \cdot 10\end{array}$ & $\begin{array}{l}52 \\
53\end{array}$ & $\begin{array}{l}04 \cdot 38 \\
64 \cdot \frac{17}{7}\end{array}$ & $\begin{array}{l}72 \\
73\end{array}$ & $\begin{array}{l}58.69 \\
58 \cdot 31\end{array}$ & \\
\hline & & 6 & $66 \cdot 15$ & 30 & $67 \cdot 05$ & 54 & $63 \cdot 96$ & 74 & $57 \cdot 92$ & \\
\hline & & 7 & $66 \cdot 27$ & $3 \mathrm{I}$ & 66.99 & 55 & 6374 & 75 & $57 \cdot 52$ & \\
\hline & & 8 & $66 \cdot 39$ & 32 & $66: 93$ & 56 & $635 \mathrm{I}$ & 76 & $57 \cdot 10$ & \\
\hline & & 9 & $66: 49$ & 33 & $66 \cdot 87$ & 57 & 63.28 & 77 & $56 \cdot 67$ & \\
\hline & & IO & $66 \cdot 58$ & 34 & $66 \cdot 80$ & 58 & 63.04 & 78 & $56 \cdot 24$ & \\
\hline & & II & $66 \cdot 66$ & 35 & $66 \cdot 73$ & 59 & 6279 & 79 & 55.79 & \\
\hline & & 12 & $66 \cdot 73$ & 36 & 66.66 & 60 & $62 \cdot 53$ & 80 & $55 \cdot 32$ & \\
\hline & & I3 & 66.80 & 37 & $66 \cdot 5^{8}$ & $6 x$ & $62: 25$ & $8 \mathrm{I}$ & $54: 84$ & \\
\hline & & I4 & $66 \cdot 87$ & 38 & $66 \cdot 49$ & 62 & $61 \cdot 96$ & 82 & $54 \cdot 35$ & \\
\hline & & 15 & $66 \cdot 93$ & 39 & $66 \cdot 39$ & 63 & $6 r \cdot 65$ & 83 & $53 \cdot 84$ & \\
\hline & & 16 & 66.99 & 40 & 66.27 & 64 & $6 I \cdot 34$ & 84 & $53 \cdot 32$ & \\
\hline & & I 7 & 67.05 & $4 \mathrm{I}$ & $66 \cdot 15$ & 65 & 6103 & 85 & $5^{2} \cdot 78$ & \\
\hline & & I8 & $67 \cdot 10$ & 42 & 66.02 & 66 & $60^{\circ} 7^{2}$ & 86 & $52 \cdot 23$ & \\
\hline & & 19 & 67.54 & 43 & 65.89 & $66 \cdot 30$ & $60^{\circ} 57$ & & & Arctic Circl \\
\hline & & 20 & 67.17 & 44 & 65.75 & 67 & $60.4 I$ & 87 & 51.68 & \\
\hline & & $2 \mathrm{r}$ & $67 \cdot 18$ & 45 & 65.60 & 68 & 60.09 & 88 & $5 \mathrm{I} \cdot 1 \mathrm{II}$ & \\
\hline & & 22 & $67 \cdot 19$ & 4.6 & 65.45 & 69 & $59^{*} 76$ & 89 & $50 \cdot 52$ & \\
\hline & & 23 & $67 \cdot 20$ & 47 & $65 \cdot 30$ & 70 & 59.42 & 90 & $49^{\circ} 9^{1}$ & Norti Pole. \\
\hline Tropic of & Cancer & $23 \cdot 30$ & $67 \cdot 20$ & 48 & $65 \cdot 13$ & 71 & $59^{\circ} 06$ & & & \\
\hline
\end{tabular}

TABLE B.-Showing the Temperature produced by Solar Radiation of the Earth's orbit; also the gradual DIMINUTION of Temperature during the first half, and the gradual INCREMENT of Temperature during the second half-year:-

\begin{tabular}{|c|c|c|c|c|c|c|c|c|c|c|c|c|c|c|c|c|c|}
\hline \multicolumn{6}{|c|}{ DATES. } & \multicolumn{2}{|c|}{ Ist. } & \multicolumn{2}{|c|}{ sth. } & \multicolumn{2}{|c|}{ Ioth. } & \multicolumn{2}{|c|}{ Isth. } & \multicolumn{2}{|c|}{ 2oth. } & \multicolumn{2}{|c|}{25 th. } \\
\hline & & Month & & & & Max. & Diff. & Max. & Diff. & Max. & Diff. & Max. & Diff. & Max. & Diff. & Max. & Diff. \\
\hline $\begin{array}{l}\text { January } \\
\text { February. } \\
\text { March } \\
\text { April } \\
\text { May } \\
\text { June } \\
\text { July } \\
\text { August } \\
\text { Septenbe } \\
\text { October } \\
\text { Novembe } \\
\text { December }\end{array}$ & $\begin{array}{l}\ldots \\
\cdots \\
\cdots \\
\cdots \\
\cdots \\
\cdots \\
\cdots \\
\ldots \\
\text { er } \\
\cdots \\
a \\
a\end{array}$ & $\begin{array}{l}\cdots \\
\cdots \\
\cdots \\
\cdots \\
\cdots \\
\cdots \\
\cdots \\
\cdots \\
\cdots \\
\cdots \\
\cdots \\
\cdots\end{array}$ & $\begin{array}{l}\ldots \\
\cdots \\
\cdots \\
\cdots \\
\cdots \\
\cdots \\
\cdots \\
\cdots \\
\cdots \\
\cdots \\
\cdots \\
\cdots\end{array}$ & $\begin{array}{l}\cdots \\
\cdots \\
\cdots \\
\cdots \\
\cdots \\
\cdots \\
\cdots \\
\cdots \\
\cdots \\
\cdots \\
\cdots \\
\cdots\end{array}$ & $\begin{array}{l}\cdots \\
\cdots \\
\cdots \\
\cdots \\
\cdots \\
\cdots \\
\cdots \\
\cdots \\
\cdots \\
\cdots \\
\cdots \\
\cdots \\
\end{array}$ & $\begin{array}{l}\text { Fah. } \\
90^{\circ} \cdot 72 \\
90 \cdot 28 \\
89 \cdot 27 \\
87.77 \\
86 \cdot 32 \\
85 \cdot 22 \\
84.84 \\
855^{\circ} \cdot 22 \\
86 \cdot 32 \\
87 \cdot 77 . \\
89 \cdot 27 \\
90^{\circ} \cdot 33\end{array}$ & $\begin{array}{l}\text { Iah. } \\
5 \cdot 88 \\
5.44 \\
4.43 \\
2 \cdot 93 \\
1 \cdot 48 \\
0 \cdot 38 \\
0 \cdot 00 \\
0.38 \\
1 \cdot 48 \\
2 \cdot 93 \\
4.43 \\
5 \cdot 49\end{array}$ & $\begin{array}{c}\text { Fah. } \\
90.70 \\
90 \cdot 16 \\
89.09 \\
87.57 \\
86.15 \\
85.13 \\
84.85 \\
85.34 \\
86.50 \\
87.97 \\
89.43 \\
90.42\end{array}$ & $\begin{array}{l}\text { Fah. } \\
5.86 \\
5.32 \\
4.25 \\
2.73 \\
1.31 \\
0.29 \\
0.01 \\
0.50 \\
1.66 \\
3.13 \\
4.59 \\
5.58\end{array}$ & $\begin{array}{l}\text { Fah. } \\
90.67 \\
90.01 \\
88.86 \\
87.32 \\
85.95 \\
85.03 \\
84.87 \\
85.49 \\
86.73 \\
88.22 \\
89.64 \\
90.52\end{array}$ & $\begin{array}{l}\text { Fah. } \\
5.83 \\
5.17 \\
4.02 \\
2.48 \\
1.11 \\
0.19 \\
0.03 \\
0.65 \\
1.89 \\
3.38 \\
4.80 \\
5.68\end{array}$ & $\begin{array}{l}\text { Fah. } \\
90.62 \\
89.83 \\
88.62 \\
87.07 \\
85.76 \\
84.96 \\
84.92 \\
85.65 \\
86.97 \\
88.47 \\
89.83 \\
90.61\end{array}$ & $\begin{array}{l}\cdot \\
5.78 \\
4.99 \\
3.78 \\
2.23 \\
0.92 \\
0.12 \\
0.08 \\
0.81 \\
2.13 \\
3.63 \\
4.99 \\
5.77\end{array}$ & $\begin{array}{l}\text { Fah. } \\
90.54 \\
89.64 \\
88.37 \\
86.83 \\
85.58 \\
84.90 \\
84.99 \\
85.83 \\
87.22 \\
88.71 \\
90.01 \\
90.66\end{array}$ & $\begin{array}{l}\text { Fah. } \\
5.70 \\
4.80 \\
3.53 \\
1.99 \\
0.74 \\
0.06 \\
0.15 \\
0.99 \\
2.38 \\
3.87 \\
5.17 \\
5.82\end{array}$ & $\begin{array}{l}\text { Fah. } \\
90.44 \\
89.43 \\
88.12 \\
86.59 \\
85.43 \\
84.86 \\
85.07 \\
86.03 \\
87.47 \\
88.95 \\
90.16 \\
90^{\circ} .70\end{array}$ & $\begin{array}{l}\text { Fah. } \\
5.60 \\
4.59 \\
3.28 \\
1.75 \\
0.59 \\
0.02 \\
0.23 \\
1.19 \\
2.63 \\
4.11 \\
5.32 \\
5.86\end{array}$ \\
\hline
\end{tabular}

TABLE C.-Temperatures produced by Solar Ractiation, Fune 26, I87I, compared with the Temperatures entered in the Table constructed 1870 , for corresponding Zenith distances. Mean discrepancy $=0.26^{\circ}$ Fah. :-

\begin{tabular}{|c|c|c|c|c|c|c|c|c|c|}
\hline & \multicolumn{9}{|c|}{ Zenith Distances-Degrees. } \\
\hline & 57 & $5^{8}$ & 59 & 60 & $6 \mathrm{I}$ & 62 & $\sigma_{3}$ & $6_{4}$ & $i 65$ \\
\hline & Fah. & Fah. & Fat. & Fah. & Fah. & Fah. & Fah. & Fah. & Fah. \\
\hline Observations June 26, I $871 \ldots$ & $55 \cdot 64$ & $55^{\circ} 00$ & $53 \cdot 83$ & $53 \cdot 5 x$ & $53 \% 4 \mathrm{I}$ & $5^{2} \cdot 76$ & $52 \cdot 23$ & $51 \cdot 70$ & $51 \cdot 27$ \\
\hline 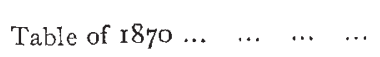 & $55^{\circ} 09$ & $54 \cdot 60$ & $54 \cdot 10$ & $53 \cdot 5^{8}$ & $53 \cdot 05$ & $52 \cdot 50$ & $51 \cdot 90$ & 5140 & $50 \cdot 81$ \\
\hline
\end{tabular}


his recent work "Le Soleil" (p. 267). "During a great number of observations made at Rome," says the author, "the difference between the two temperatures (that indicated by the thermometer exposed to the sun and that of the surrounding casing), was $12.06^{\circ}\left(21^{\circ} 70^{\circ} \mathrm{Fah}\right.$.) ; during days when the sky was clearer, it rose to $14^{\circ} . "$ Consequently, the highest temperature indicated by the instrument referred to, was $25^{\circ} 2^{\circ}$ Fah., against $66^{\circ} 04^{\circ}$, which is the true maximum solar intensity in the latitude of Rome. It will be seen then, that, by exposing the bulb of the thermometer in the manner pointed out, it is possible to reduce the temperature produced by solar radiation to 0.38 of the actual temperature.

It will be proper to observe with reference to the accompanying tables-constructed in accordance with the result of investigations continued winter and summer during three years - that the opinion expressed by the Director of the Roman Observatory, respecting solar intensity at different seasons, is wholly at variance with the facts established by my numerous observations. The question was raised last summer whether the high temperature during the "heated term" would not charge the atmosphere with an additional amount of vapour capable of retarding the passage of the heat rays, thus rendering the figures entered in my tables to some extent unreliable. Accordingly, during the solstice June 26, 187r, the sky being very clear, the actinometer was put in operation for the purpose of ascertaining with critical nicety whether the atmosphere which had been loaded with vapour for several weeks previously possessed any unusual property tending to check the heating power of the sun's rays. The observations were made late in the afternoon under great zenith distance and increased atmospheric depth, in order to subject the heat rays to an additional retardation from the supposed vapours. The result is recorded in Table $C$, by which it will be seen that the reduction of temperature was only $026^{\circ}$ Fah., a difference too small to call for any explanation. The result of the observations made during midwinter are equally conclusive with reference to the permanency of solar energy at all seasons. Among others may be mentioned that of January 17 , I $87 \mathrm{I}$, the zenith distance being $6 \mathrm{I}^{\circ} 30^{\prime}$, the actinometer remained perfectly stationary at $58^{\circ} 73^{\circ} \mathrm{Fah}$, from $\mathrm{I} 2 \mathrm{~h}$. Iom. to $12 \mathrm{~h}, 2 \mathrm{om}$. P.M. The table just referred to shows that on June 26,1871 , the actinometer indicated $53^{\circ} 08^{\circ}$. when the sun's zenith distance was $61^{\circ} 30^{\prime}$. Hence during midwinter the temperature proved to be $58^{\circ} 73^{\circ}-53^{\circ} 08^{\circ}=5^{\circ} 65^{\circ}$ higher, for corresponding zenith distance, than during the summer solstice. By reference to Table $B$ it will be seen that owing to the diminished distance between the sun and the earth, the increment of temperature on January 17 , ought to have been $575^{\circ}$, discrepancy $=0^{\circ} 1^{\circ} \mathrm{Fah}$. In the face of such facts it is idle to contend that the temperature produced by solar radiation under corresponding zenith distance and a clear sky, varies from any other cause than the varying distance between the sun and the earth. Of course there are many regions in which the sun, in consequence of local peculiarities, but seldom acts with maximum energy. Alaska, for instance, is hardly ever favoured with a full amount of solar heat; nor does Rome, we are now informed by the Italian physicist, receive maximum solar heat excepting during winter, owing, it may be imagined, to the absorptive power of the atmosphere of the Campagna during summer.

Without entering the field of speculation, let us consider that the established diminution of solar heat on the ecliptic, nearly $18^{\circ} \mathrm{Fah}$., proves the existence of a powerful retarding medium, and points to the presence of a permanent mass of aqueous matter in the higher regions of the atmosphere; necessary, it may be urged, to regulate terrestrial temperature and render vegetable life possible under the destructive vicissitudes of heat and cold, inevitable in the absence of a permanent regulator. The assumption that the supposed mass of aqueous matter is nearly invariable, and at all times present, can alone account satisfactorily for the remarkable fact that, whenever a clear sun is presented, either by the opening of the clouds or by their disappearance, the actinometer indicates the same temperature, subject only to the variations depending on the sun's zenith distance, and the varying position of the earth in its orbit. The variation of temperature produced by the latter cause is entered in Table B, for every fifth day in each month. This table, an extract from a more elaborate one showing the temperature for every day in the year, the meteorologist will find indispensable to harmonise observations made at different seasons. It may be mentioned that the attempt to construct a curve, the ordinates of which would determine the temperature for different zenith distances, at first met with apparently insuperable difficulty. The result of observations made at different seasons under the most favourable circumstances, failed to produce a regular curve until the change of temperature corresponding with the varying distance between the sun and the earth was determined and introduced in the calculation. This at once harmonised the previously conflicting observations, and rendered the task easy of perfecting the curve, and obtaining ordinates consistent with the observed temperature produced by solar radiation at different seasons and different zenith distance.

Regarding Table A, it will suffice to state that it is based upon our acquired knowledge of the temperature produced by solar radiation at given zenith distances when the earth is in aphelion. Evidently if we know that, for instance, when the sun's zenith distance is $43^{\circ}$ the temperature is $60^{\circ} 57^{\circ} \mathrm{Fah}$., we know also that this is the temperature at noon on the Arctic Circle, the latter being $43^{\circ}$ from the ecliptic at the summer solstice. Again, the North Pole being $66^{\circ} 30^{\prime}$ from the ecliptic at the same time, we find by referring to the figures entered in the table of zenith distances and temperatures (previously publish.ed) that the depth of atmosphere to be penetrated by the rays when the sun is $66^{\circ}, 30^{\prime}$ from the zenith, is 2.444 times greater than on the ecliptic; and that, therefore, the radiant intensity, as shown in the table, is reduced from $677^{\circ} 20^{\circ}$ at the tropic of Cancer to $49^{\circ} 91^{\circ} \mathrm{Fah}$. at the pole. Possibly it may be found necessary to introduce a correction for the difference of atmospheric density in the higher latitudes; but at present I deem it inexpedient to complicate the matter by applying a correction which obviously cannot affect the general result.

\section{J. ERICSSON}

\section{NOTES}

THE Anniversary Meeting of the Royal Society will be held on the 3oth inst., when Sir Edward Sabine will celiver his eleventh and last anniversary address. Prof. G. B. Airy, the Astronomer Royal, will be brought forward as his successor.

AT the opening meeting for the session of the Royal Geographical Society, on Monday evening last, the president, Sir H. Rawlinson, annotinced that, in consideration of Dr. Livingstone's services, Her Majesty's Government had been pleased to grant to his children the sum of $300 l$.

THE following are the lecture arrangements for $1871-72$ at the Royal Institution, Albemarle Street:-Prof. Tyndall, F.R.S. : six lectures on "Ice, Water, and Air," on December 28, 30, I871 ; January 2, 4, 6, 9, I872. Dr. W. Rutherford, F.R.S.E. ten lectures on "The Nervous and Circulatory System," on Tuesdays, January I6 to March 19. Prof. Odling, F.R.S. : ten lectures on "The Chemistry of Alkalies and Alkali Manufacture," on Thursdays, January i I to March 2I. Mr. W. G. Clark, late Public Orator: six lectures on "The History of Dramatic Literature, Ancient and Modern," on Saturdays, January 20 to Feb. 24. Mr. Moncure D. Conway: four 